\title{
Development of a High Accuracy Harmonious Control Method for Push-up Jack System for Building Construction
}

\author{
Tsutomu Tomita*, Sumihiro Ueda**, Yukitada Ogihara***, Takezo Miyamoto**** \\ * Steel Structure Division, Kawasaki Heavy Industries, LTD. \\ 11-1, 2-Chome Minamisuna, Koto-ku, Tokyo. 136 JAPAN \\ ** Electronic \& Control Technology Center, Kawasaki Heavy Industries, LTD. \\ 118 Futatsuzuka, Noda, Chiba. 278 JAPAN \\ *** Architectural Technology Division, Kajima Corporation \\ Pair Horse Building, 5-16 Akasaka 6-Chome, Minato-ku, Tokyo. 107 JAPAN \\ **** Machinery \& Equipment Division, Kajima Corporation \\ Fujikage Bldg. 1-1-5 Motoakasaka, Minato-ku, Tokyo. 107 JAPAN
}

\begin{abstract}
These days in Japan there are a lot of demands for middle- or high-story buildings, ranging from 9 to 15 stories. When constructing these buildings, various kinds of improvements have been accomplished so far ; adoption of pre-cast concrete components, optimized combination of steel, concrete and other materials, development of all-weather construction methods in which top-story building structures are utilized as all-weather covers. As results of these technological accomplishments, construction costs have been minimized and construction periods shortened. The building construction methods of today, in which a story is stacked on the preceding lower stories and the working site moves upward story by story, have thus been improved so ideally that some breakthrough would be necessary to go further. We have made another challenge to go further; we have developed a new all weather construction technology, in which a building structure is constructed on the ground level, in which upper stories are pushed up by a newly developed jack system and a lower story is constructed under the raise upper stories repeatedly. Our new system, with which not only steel structure building but also reinforced concrete buildings of 9 to 15 stories can be constructed, required us to develop a very high accuracy harmonious control method for a plurality of large capacity jacks. The authors have carried out a series of simulations by CAE(Computer Aided Engineering) methods, designed a new control system, developed a control system and proved its effectiveness by a series of tests.
\end{abstract}




\section{INTRODUCTION}

Generally speaking in Japan improvements of productivities in the field of building construction have been rather slow when compared with those in the fields of manufacturing. These a day, however, civil constructors tend to make efforts to improve their productivities, in order to confront economical recession, decrease of business chances, decrease of supply of younger laborers, and so forth. They are aiming to develop CIC(Computer Integrated Construction), and in those back-grounds "all-weather construction system for building" gather attentions, which enable civil constructors to continue construction in any weather, and some systems have already been actually applied.

We have developed our own all -weather construction method, which differs from most of the other all-weather construction methods, which can be carried out at ground level, and we call it " $\mathrm{A}$ " Method temporarily in this paper. Here, in this paper, we are introducing the newly developed construction method, focusing its high-accuracy harmonious control method to control the push-up jack system consisting of a plurality of large capacity jacks.

\section{Features of Upper Stories Up Method}

Table 1 shows the outstanding features of "A "method in comparison with the other all-weather type stacking-stories-up methods.

Table 1 Comparison of All-weather Construction Methods

\begin{tabular}{|c|c|c|}
\hline Method & $\begin{array}{l}\text { All-weather type Stacking- } \\
\text { Stories-Up Methods }\end{array}$ & "A" Method \\
\hline $\begin{array}{l}\text { Buildings to be } \\
\text { constructed }\end{array}$ & $\begin{array}{l}\cdot \text { Higher than } 20 \text { story } \\
\text { buildings } \\
\cdot \text { Mainly steel structure }\end{array}$ & $\begin{array}{l}\cdot 9 \text { to } 15 \text { story buildings } \\
\cdot \text { steel structure } \\
\cdot \text { steel-RC structure } \\
\cdot \text { RC- structure }\end{array}$ \\
\hline Circumstance & - all-weather & -all-weather \\
\hline Working floor level & $\begin{array}{l}\text { working floor moves up } \\
\text { story by story }\end{array}$ & - At ground level \\
\hline $\begin{array}{l}\text { Location of } \\
\text { construction Facilities }\end{array}$ & -At up-the-most floor & - At ground level \\
\hline Appearance & \begin{tabular}{|l|}
$\cdot$ Heavy construction \\
facilities installed at top of \\
building during \\
construction
\end{tabular} & $\begin{array}{l}\text { Completed building } \\
\text { grows upward }\end{array}$ \\
\hline Material handling & $\begin{array}{l}\text { Materials are carried } \\
\text { vertically \& horizontally }\end{array}$ & $\begin{array}{l}\text { - Materials are carried } \\
\text { horizontally at ground } \\
\text { level }\end{array}$ \\
\hline
\end{tabular}


Thus, "A" method has many outstanding features, but at the same time, in order to embody it we had to develop several new technologies. Of them all, development of a new pushing -up jack system was the most important. Table 2 shows the specification of the newly developed pushing-up jack system for "A "method.

Table 2 Specification of Pushing.Up Jack System for "A" Method

\begin{tabular}{|c|c|c|}
\hline & Specification & Completed First System \\
\hline $\begin{array}{l}\text { Buildings to be } \\
\text { constructed }\end{array}$ & $\begin{array}{c}9 \text { to } 15 \text { story building } \\
\cdot \text { steel structure } \\
\cdot \text { RC structure } \\
\cdot \text { Steel-RC structure }\end{array}$ & $\begin{array}{l}\text { First building: } \\
\text {-9 story apartment } \\
\text { house }\left(4,216 \mathrm{~m}^{2}\right) \\
\text { - Steel-RC structure } \\
\text { Second building: } \\
\text { - } 11 \text { story office building } \\
\text { - Steel structure } \\
\text { The jack system is to be utilized } \\
\text { repeatedly site after site. }\end{array}$ \\
\hline Composition & $\begin{array}{l}\text { One system comprised of } \\
16 \text { jacks, the capacities of } \\
\text { which are } 400 \text { tons, } 600 \\
\text { tons, } 800 \text { tons. }\end{array}$ & $\begin{array}{c}\text { First set comprised of } \\
600 \text { ton jack x } 6 \\
400 \text { ton jack x } 4\end{array}$ \\
\hline $\begin{array}{l}\text { Jack Specification } \\
(\text { in case of } 600 \text { tons) }\end{array}$ & \multicolumn{2}{|c|}{$\begin{array}{l}\text { Type: Electrical-motor driven screw rod \& supporting } \\
\text { frame } \\
\text { Dimension: } 4,000 \mathrm{~mm} \times 2,550 \mathrm{~mm} \times 5,275 \mathrm{~mm} \\
\text { Weight: Approximately } 50 \text { tons } \\
\text { (Frame can be taken into } 10 \text { pieces for convenience of } \\
\text { transportation.) } \\
\text { Drive Component: } 15 \mathrm{~kW} \text { motor-Inverter x } 2 \\
\quad 240 \mathrm{~mm} \text { dia. screw rod x } 2 \\
\text { Push-up speed: } 15 \mathrm{~mm} / \mathrm{min} \text {. }\end{array}$} \\
\hline $\begin{array}{l}\text { Pushing-up } \\
\text { accuracy }\end{array}$ & $\begin{array}{l}<1 \mathrm{~mm} \text { within jack } \\
<3 \mathrm{~mm} \text { between neighbori } \\
<10 \mathrm{~mm} \text { in total system }\end{array}$ & ing jacks \\
\hline
\end{tabular}

Each of the jack is composed of a supporting frame, a traveling block, two load-cell-mounted loading arms, two screw rods and nuts, two electrical drive units and control system. The jack scoop up building structure beams at both sides of each building column with a couple of the loading arms each, just like a fork lift, moves vertically up the building continuously by designed stroke: $3,250 \mathrm{~mm}$ in case 
of the first building, holds it for a week, while the building structure of the lower story is assembled beneath it, and lower it until the bottoms of the columns touch the load bearing components on ground and until the jack becomes unloaded. Then the loading arms descend down and scoop the building again, this time, pushing up the beams of the lower story.

Figure 1 and 2 show the jack structure and the construction image of the first application of the jack system, respectively.

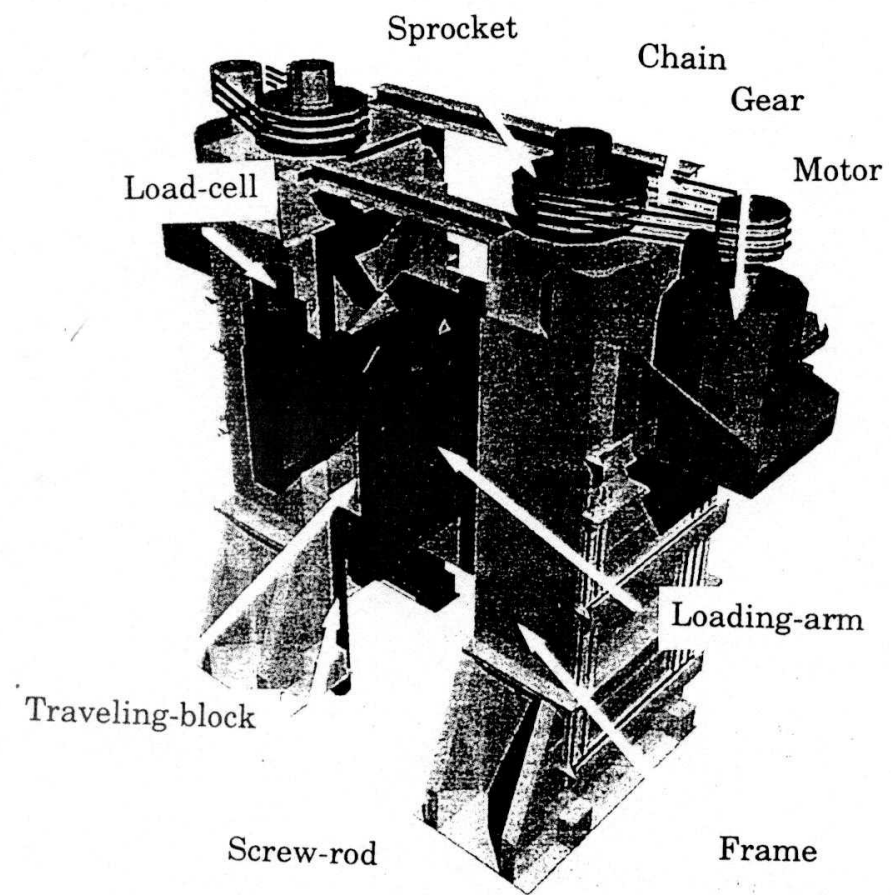

Figure 1 Structure of Jack for "A" Method

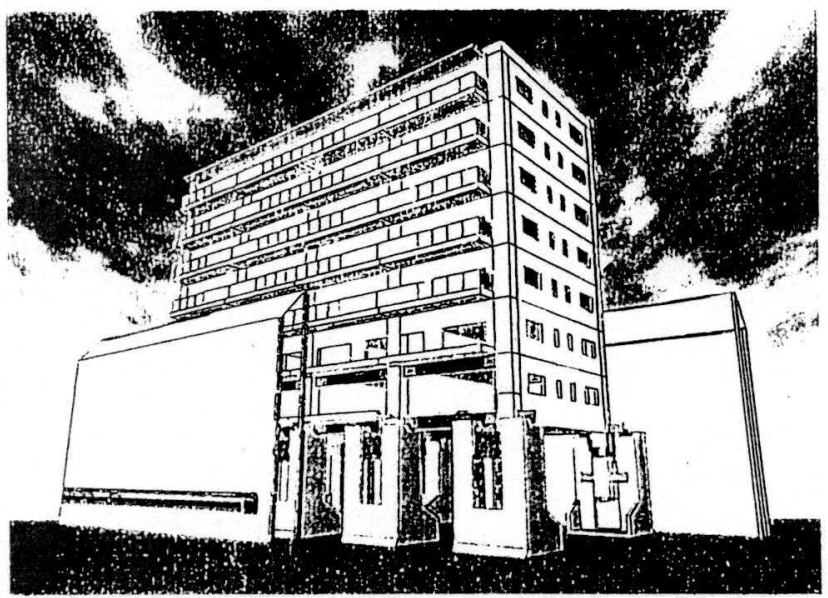

Figure 2 First Application of "A" Method 


\section{Design of High-accuracy Harmonious Control System}

\subsection{Single Jack Behavior Simulation using CAE}

First, we carried out a series of computer simulation using CAE in order to verify the pushing-up behaviors of single jack structure. In this simulation, we modeled the jack with a plurality of masses, springs and two actuators, and analized the displacement, velocity and constrained force of each part of jack at the time of pushing-up. Fig3, 4 and 5 show the CAE model, an example of its 3D graphic model and analized results respectively.

We verified that, with our jack system, highly acurate and harmonious pushingup behavior of two screws were attained.

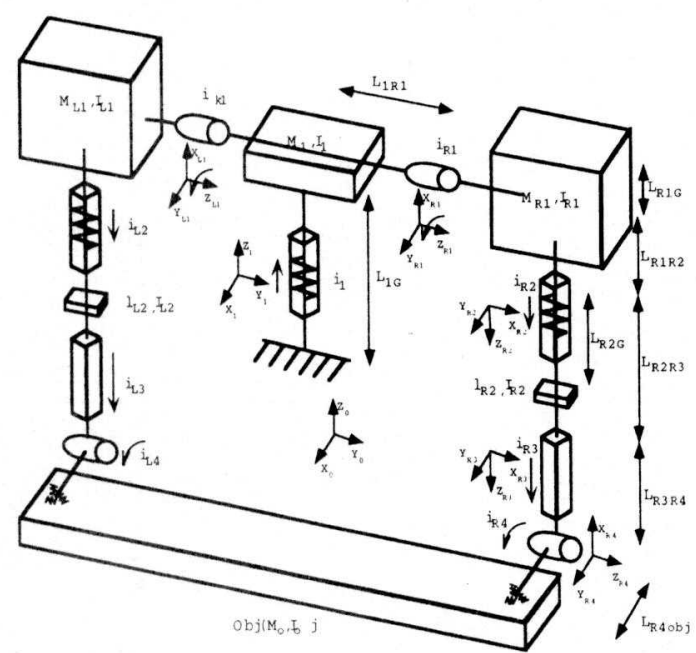

Fig.3 CAE Model of Jack

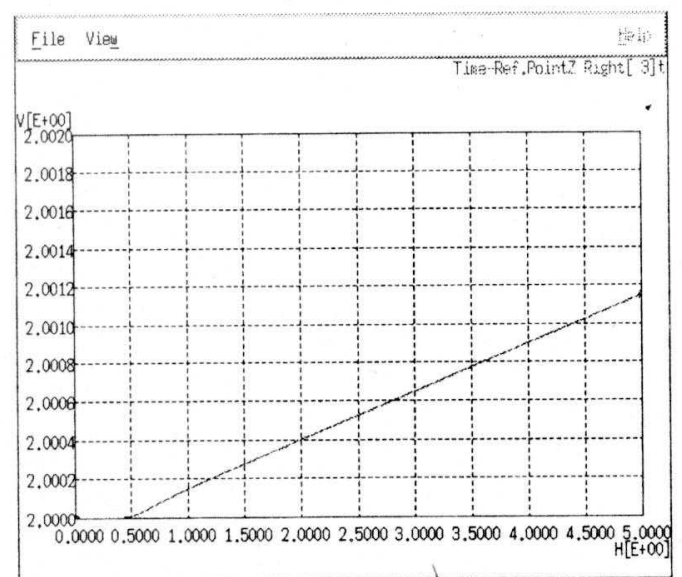

(a)Position

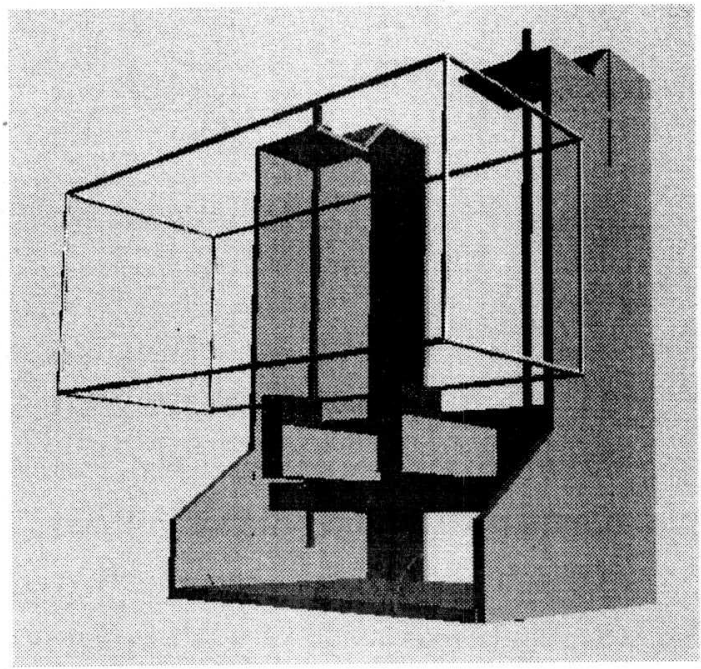

Fig.4 3D Graphic Model

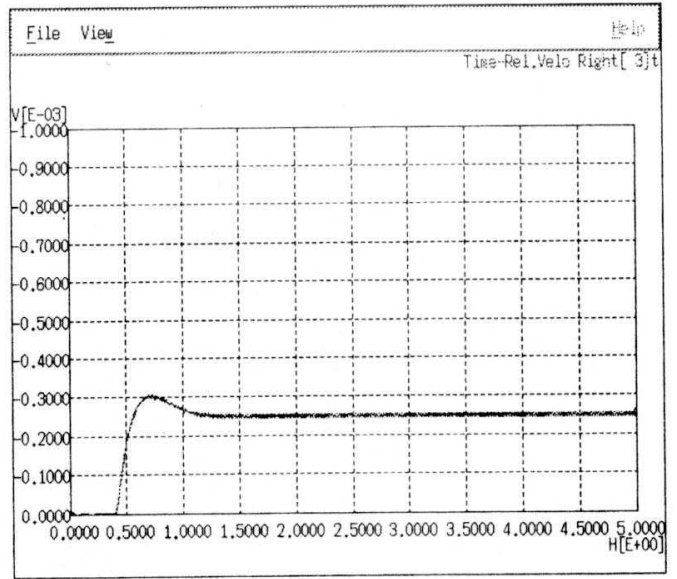

(b)Velocity

Fig.5 Example of Response 


\subsection{Harmonious Behavior Simulation using CAE}

Next, we studied the validity of our harmonious control design of plural jacks. The heights of loading arms of each jack are controlled by feed-back system and the compensation from this loop is added to velocity feed-forword. Furthermore, the output from harmonious control block corrects the height reference of each jack. Fig.6 shows the block diagram of the control system.

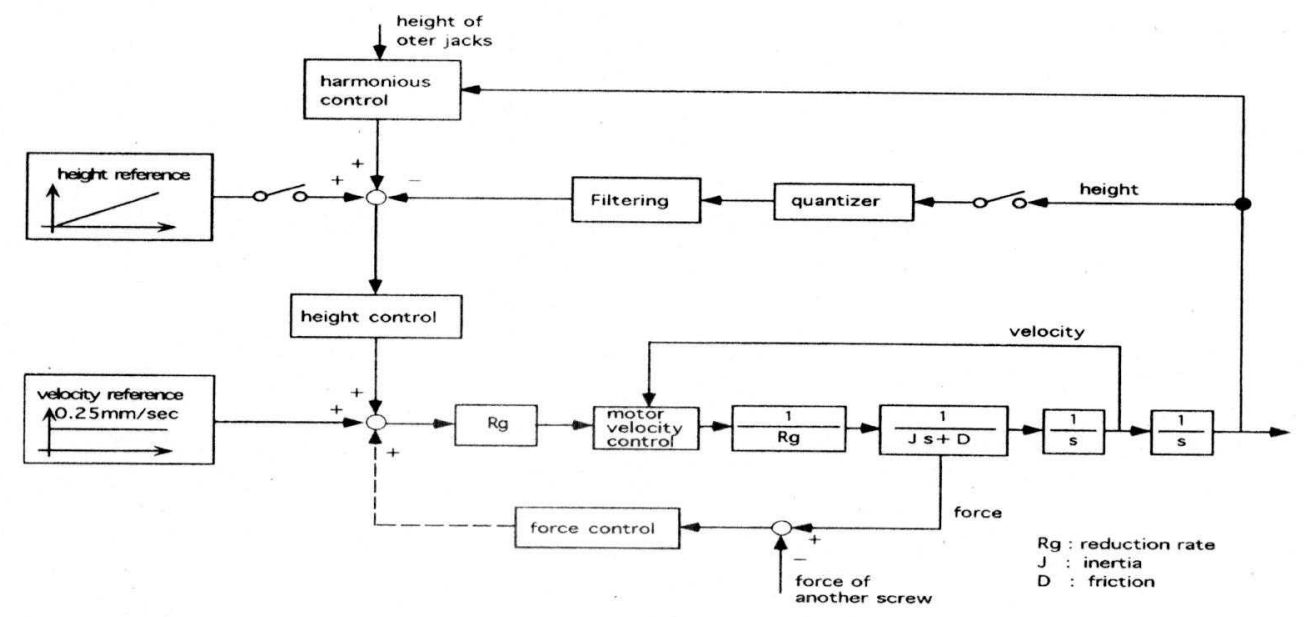

Fig.6 Block Diagram of Control System

Fig.7 shows the block diagram of harmonious control. Our concept of harmonious control is as follows.

(1)Each jack's height is controlled in local.

(2)The target value for all jacks is caluclated from the height of each jack. (3)The height reference of each jack is corrected on the differnce between the each height and target value.

In practical application, we use proportional, integral,phase lead-lag element...etc, as a compensator and set the maximum height as target value. Fig. 8 shows the simulation results. In these simulations, we delay the reference of one jack intentionally and confirm the validity of our harmonious control method.

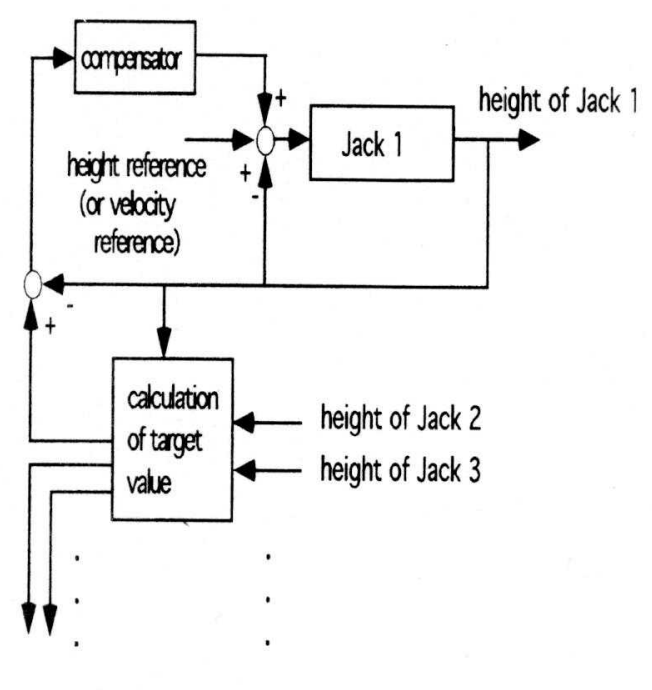

Fig.7 Harmonious Control Block Diagram 

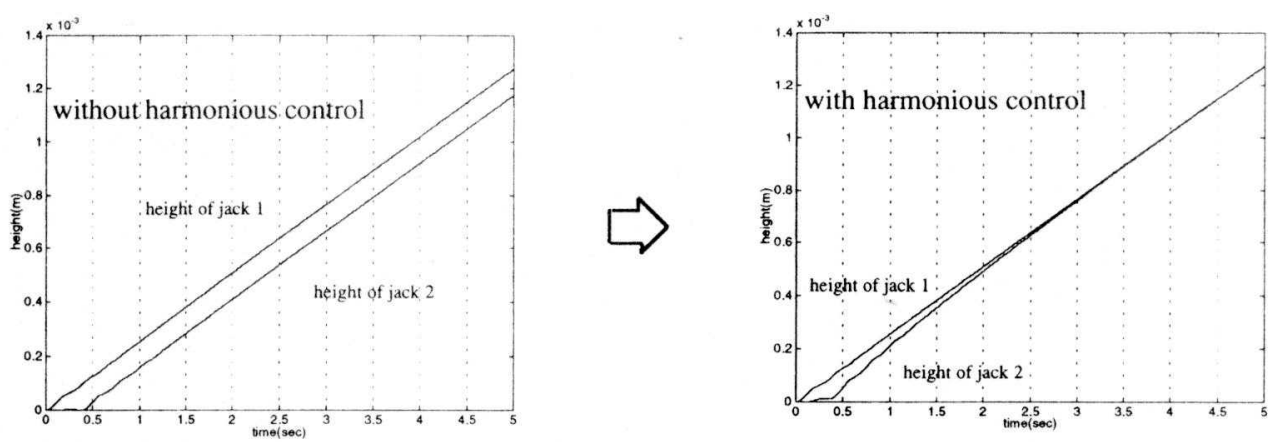

Fig. 8 simulation results of harmonious control

When we use two-screws type jack, they must be controlled harmoniously with accuracy. If the accuracy of height sensor is not enough, we can add force control loop to height loop. Fig.9 shows force control block diagram and Fig.10 shows simulation results.

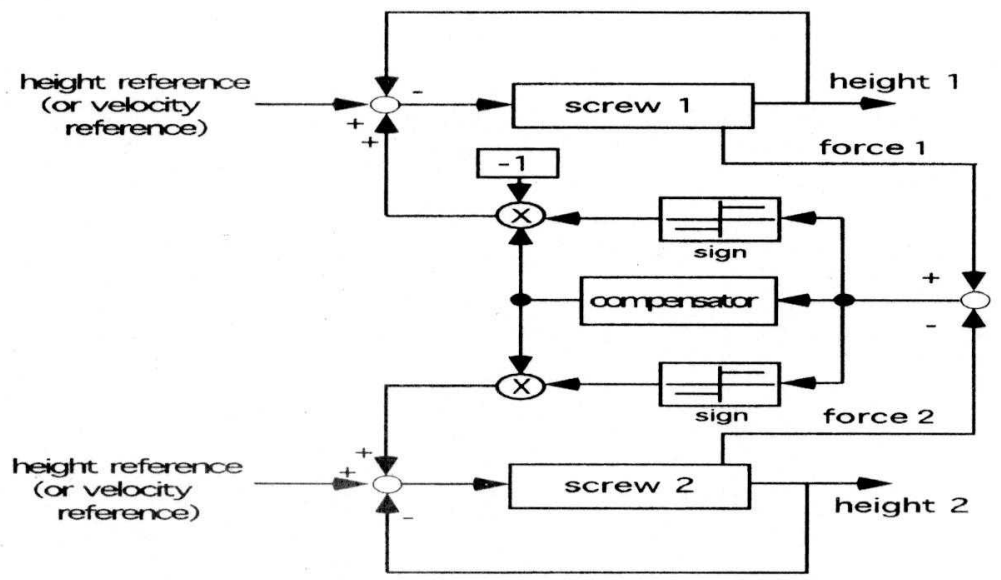

Fig.9 Force Control Block Diagram
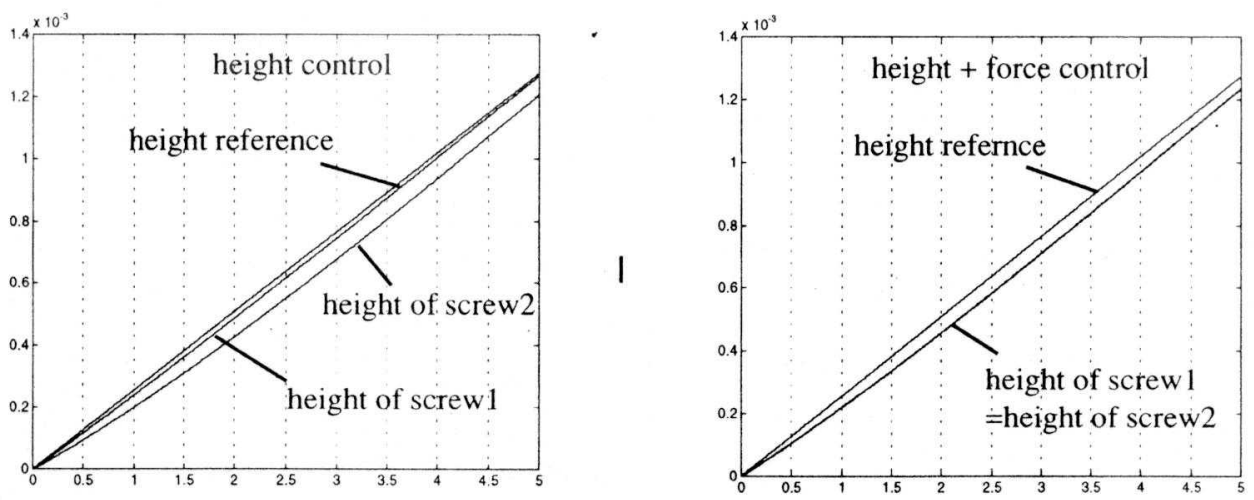

Fig.10 Simulation Results of Force Control 


\section{Control system configuration}

Figure 11 shows configuration of control system . Magnetic type digital linear scale are used for measuring pushing-up height to control accuracy. Also load-cells are used for monitoring loads. If a load-cell detects an abnormal load, the digital servo controller stops to push-up.

The digital servo controller consists of 32 bits CPU, high speed serial communication chip and etc. The controller and the linear scale are backed up by non-stop power supply device.

Figure 12 shows example of monitor panel in the central controller. An operator watch circumstances easily by graphical display.

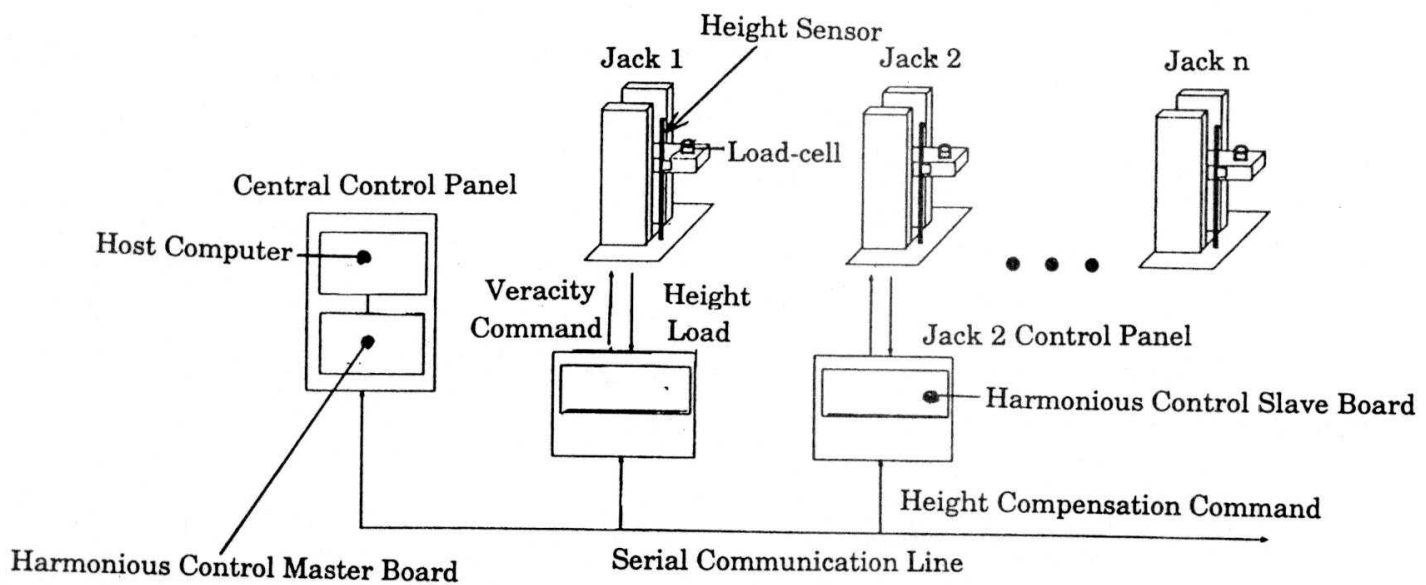

Figure 11 Configuration of Control System

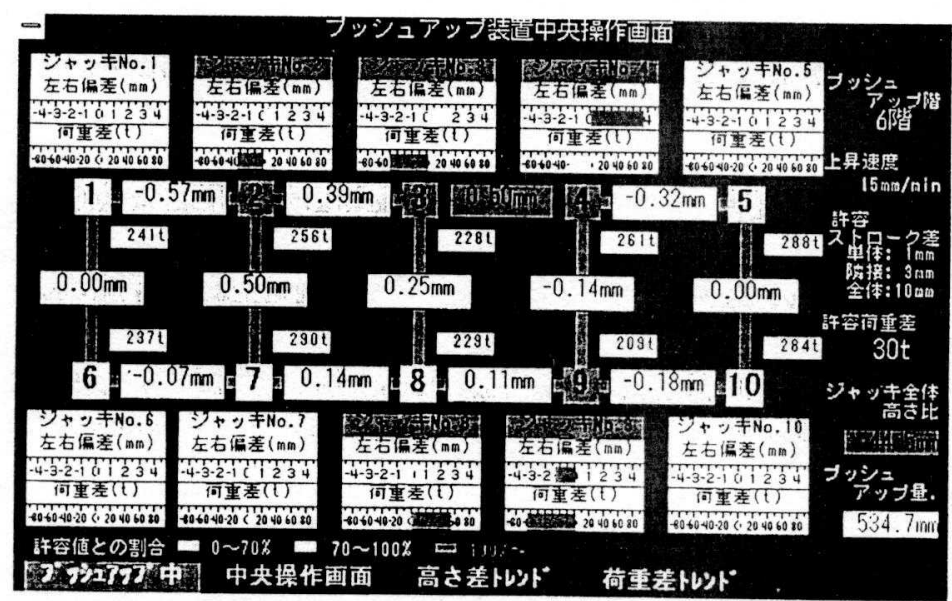

Figure 12 Example of Monitor Panel in Central Controller 


\section{Test}

Figure 13 shows circumstances of load test and harmonious control test. On these test push-up jack is loaded by hydraulic jack instead of building weight. Figure 14 shows a result of harmonious test. Push-up accuracy were satisfied specifications in spite of change of load.

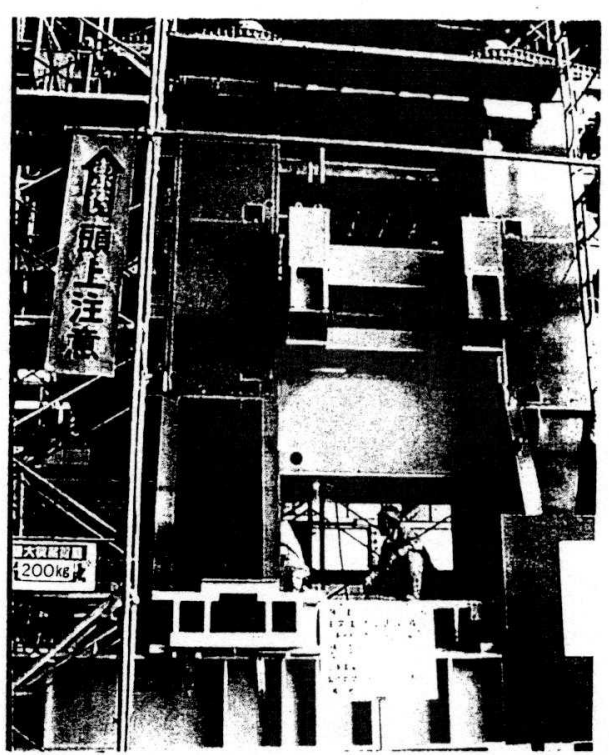

Figure 13 Circumstances of Load Test and Harmonious Control Test

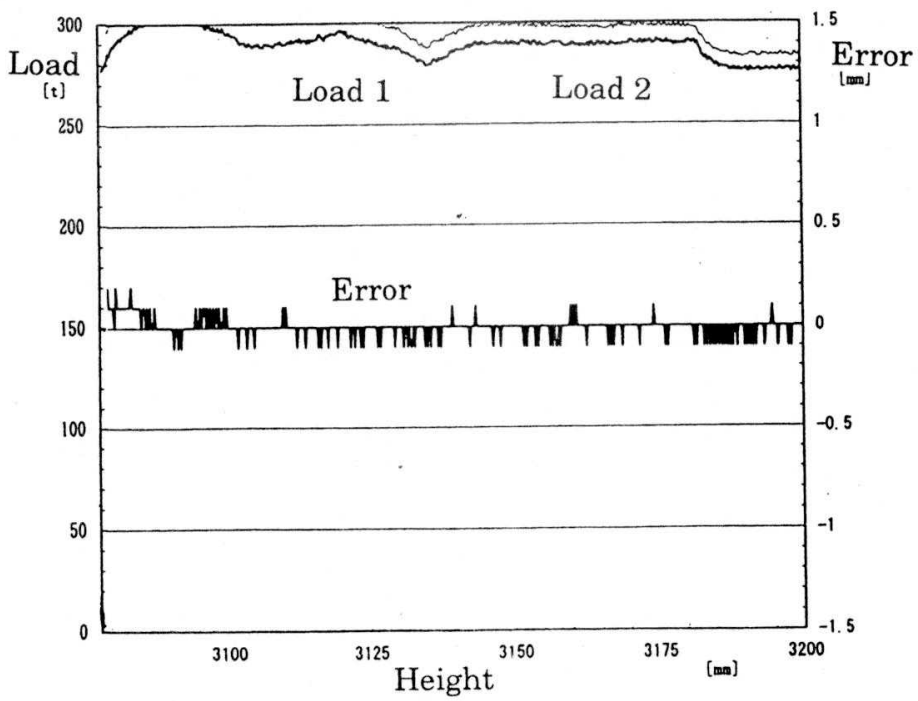

figure 14 A Result of Harmonious Test 


\section{Conclusion}

The authors developed electric-motor-driven push-up jack system that is controlled very high accuracy by harmonious controller. This new building construction method can be used not only steel structure building but also reinforced concrete buildings of 9 to 15 stories. We hope this new method will be popularized by reason of its excellent features.

The construction by "A" method have started in February 1996 and now continues.

\section{REFERENCES}

[1] S. Hattori, "Features: Building Construction System", NIKKEI MECHANICAL, 1993.4.5, pp. $42-53$

[2] K. Ioi, et. al., "Development of a CAE System for Mechanism and Control System Design", Kawasaki Technical Review, pp. 50-55 (Oct. 1994)

[3] T. Miyamoto, "An Outline of Automatic Construction System (Grow-Up Construction Method) ", Proceedings, Symposium on Japan Material Handling Association, pp. 7-10 (Nov. 1995) 